$11-2016$

\title{
A Critique of Henrik Friberg-Fernros's Defense of the Substance View
}

William Simkulet

Cleveland State University, w.simkulet@csuohio.edu

Follow this and additional works at: https://engagedscholarship.csuohio.edu/clphil_facpub

Part of the Bioethics and Medical Ethics Commons, and the Philosophy Commons

How does access to this work benefit you? Let us know!

Publisher's Statement

Copyright Wiley Online Library. This article first appeared in Bioethics. 2016 Nov; 30(9):767-773. doi: $10.1111 /$ bioe. 12289 .

\section{Original Citation}

Simkulet, W. "A Critique of Henrik Friberg-Fernros's Defense of the Substance View." Bioethics. 2016 Nov; 30(9):767-773. doi: 10.1111/bioe.12289. Epub 2016 Sep 30.

This Article is brought to you for free and open access by the Philosophy \& Comparative Religion Department at EngagedScholarship@CSU. It has been accepted for inclusion in Philosophy \& Comparative Religion Department Faculty Publications by an authorized administrator of EngagedScholarship@CSU. For more information, please contact library.es@csuohio.edu. 


\title{
A CRITIQUE OF HENRIK FRIBERG-FERNROS'S DEFENSE OF THE SUBSTANCE VIEW
}

\author{
William Simkulet
}

\begin{abstract}
Proponents of the substance view contend that abortion is seriously morally wrong because it is killing something with the same inherent value and right to life as you or 1 . Rob Lovering offers two innovative criticisms of the anti-abortion position taken by the substance view - the rescue argument and the problem of spontaneous abortion. Henrik Friberg-Femros offers an interesting response to Lovering, but one 1 argue would be inconsistent with the anti-abortion stance taken by most substance view theorists.
\end{abstract}

Keywords: abortion, substance view, Rob Lovering, Henrik Friberg-Fernros, spontaneous abortion

\section{A CRITIQUE OF HENRIK FRIBERG- FERNROS'S DEFENSE OF THE SUBSTANCE VIEW}

Proponents of the substance view contend that abortion is seriously morally wrong because it is the killing of something with the same right to life as you or I. In his recent article The Substance View: a Critique ${ }^{1}$ Rob Lovering offers two compelling arguments against the substance view. First, Lovering asks us to consider a scenario in which rescuers have to choose between saving either a 10 year old boy or an embryo. The substance view theorist seems to be committed to the position that both the boy and the embryo are morally equivalent, and thus saving either would be morally justified; Lovering however contends that most of us would choose to save the boy, suggesting we believe the boy has more moral worth than the embryo. Call this the rescue argument. Second, he criticizes the substance view theorist for their inattention to spontaneous abortions, which it is estimated end $60 \%$ of pregnancies. ${ }^{2}$ Call this the problem of spontaneous abortion.

' R. Lovering. The Substance View: A Critique. Bioethics 2012; 27(5): 263270.

2 C.E. Boklage. Survival Probability of Human Conceptions from Fer tilization to Term. Int J Fertil 1990; 35(2): 75 94; H. Leridon. 1977. Human Fertility: The Basic Components. Chicago, IL: Chicago Univer sity Press.
In A Critique of Rob Lovering's Criticism of the Substance View ${ }^{3}$ Henrik Friberg-Fernros replies to these arguments. First, Friberg-Fernros contends that the relevant difference between the 10-year-old boy and the embryo is that one has greater time relative interests than the other. Call this the time relative interests reply. Second, he argues that because most spontaneous abortions are impossible to prevent, we cannot have a moral obligation to prevent them. Furthermore, he contends, because of the relatively low time relative interests of the spontaneously aborted embryos, their deaths are less bad than the death of human infants.

Here I argue that Friberg-Fernros's response fails to adequately address the problems raised by Lovering. First, by relying upon time relative interests to explain the greater badness resulting from the deaths of non-fetuses, he undermines the substance-view's anti-abortion claim that the death of a fetus is the same kind of harm as our deaths; for Friberg-Fernros the loss of a human fetus whether in a disaster or via spontaneous abortion is a much lesser loss than the loss of you or me. ${ }^{4}$ This stance would severely undermine the substance view's criticism of abortion. Second, Friberg-Fernros misses the point of the problem of spontaneous abortion; Lovering contends

\footnotetext{
${ }^{3}$ H Friberg Fernros. A Critique of Rob Lovering's Criticism of the Sub stance View. Bioethics 2015;29(3):211 216.

${ }^{4}$ Ibid: 212.
} 
that spontaneous abortion is the loss of something the substance view identifies as valuable. Even if these deaths are entirely outside of our control and their lives less valuable than non-fetuses (as Friberg-Fernros seems to hold)

for the substance view their deaths still matter, yet it seems that we ignore them entirely. We do not mourn the loss of spontaneously aborted children; yet the substance view is committed to the proposition that the loss of spontaneously aborted children is comparable to the loss of you or me. If this is the case, then our attitudes towards spontaneous abortion are morally negligent.

\section{THE SUBSTANCE VIEW}

According to many proponents of the substance view: ${ }^{5}$

(1) You and I are essentially rational agents.

(2) Rational agents are inherently valuable. (All else being equal, the loss of such a being is seriously morally bad.)

(3) Rational agents have a right to life. (All else being equal, it is seriously wrong to kill such a being.)

With regard to abortion, substance view theorists hold:

(4) Human fetuses are, from the moment of conception, rational agents. ${ }^{6}$

${ }^{5}$ F. Beckwith. 2007. Defending Life: A Moral and Legal Case Against Abortion Choice. New York, NY: Cambridge University Press; P. Lee \& R.P. George. 2007. Body Self Dualism in Contemporary Ethics and Poli tics. Cambridge, UK: Cambridge University Press; P. Lee \& R.P. George. The Nature and Basis of Human Dignity. Ratio Juris 2008; 21(2): 179 193; P. Lee. The Pro Life Argument from Substantial Identity: A Defense. Bioethics 2004; 18(3): 249 263; P. Lee \& R.P. George. The Wrong of Abortion. 2005. In Contemporary Debates in Applied Ethics. A.I. Cohen \& C.H. Wellman, eds. Oxford, UK: Blackwell Publishing: 13 26; R.P. George \& C. Tollefsen. 2008. Embryo: A Defense of Human Life. New York, NY: Doubleday; F. Beckwith. 2007. Defending Life: A Moral and Legal Case Against Abortion Choice. New York, NY: Cambridge University Press. P. Lee \& G. Grisez. Total Brain Death: A Reply to Alana Shewmon. Bioethics 2008; 26(5): 275 284. P. Lee, C. Tollefsen \& R.P. George. The ontological status of embryos: a reply to Jason reMorris. J Med Philos 2014; 39(5): 483504.

${ }^{6}$ By 'human fetus' here I mean to pick out any developing biologically human organism. There is important and nuanced debate about whether such a being at its earliest of stages is numerically and/or personally iden tical to the adult human organism that it will become; for the purposes of this paper I will assume that this is the case, as most substance view theorists do. Regarding the identity debate, Jeff McMahan contends that we are essentially psychological agents, numerically distinct from our bodies, and do not come into existence until after our brains develop, while others such as Don Marquis, Barry Smith and Bergit Bro gaard contend that a single human organism does not come into exis tence until after cell specialization begins. See: J. McMahan 2002. The Ethics of Killing: Problems at the Margins of Life. New York: Oxford University Press; B. Smith \& B. Brogaard. Sixteen Days. J Med Philos2003; 28(1):45 78; D. Marquis. The Moral Principle Objection to Human Embryonic Stem Cell Research. Metaphilosophy 2007; 38(2 3): 190206.
(5) Therefore human abortion - the killing of human fetuses - is the killing of inherently valuable beings with a right to life, and thus all else being equal, seriously morally wrong. (From (2), (3) and (4).)

Human fetuses do not exhibit first-order rationality, or the capacity to immediately engage in rational deliberation; however substance view theorists contend that what matters, morally, is second-order rationality, or the capacity to develop first-order rationality at some point in the future (given the appropriate conditions). ${ }^{7}$ Proponents of the substance view believe that what matters, morally, is being the kind of thing that possesses secondorder rationality; first-order rationality is merely an accidental trait. (For substance view theorists at least those opposed to abortion a thing undergoes a substantial change when it gains or loses the second-order capacity for rationality, but doesn't undergo a substantial change when it gains or loses the first-order capacity for rationality. $)^{8}$ Substance view theorists sometimes talk as though what matters is being a human or a person; for example Friberg-Fernros says 'Proponents of the substance view hold that abortion is wrong because the embryo is already a human person and, as such, entitled to basic human rights." However substance view theorists would also hold that that non-biologically human persons, like angels or visitors from space, would matter morally, so long as they have the second-order capacity for rationality.

\subsection{The Rescue Argument}

Lovering asks us to consider the following hypothetical situation:

Rescue: During hurricane Katrina, police officers face a choice: save a frozen human embryo or save a ten-year-old boy. The officers choose to save the frozen embryo. When asked why, the officers replied that they couldn't save both and because both the embryo and the 10-year-old boy were of equal standing, they flipped a coin. ${ }^{10}$

\footnotetext{
${ }^{7}$ See: P. Lee and G. Grisez. Total Brain Death: A Reply to Alan Sheow mon. Bioethics 2012; 26(5): 275284.

${ }^{8}$ To illustrate this, consider Michael Tooley's well known example of a kitten that is injected with a chemical that will turn it into a person in nine months. When injected, the kitten is given the second order capacity for rationality, but will only obtain the first order capacity for rationality after nine months. In personal correspondence, Patrick Lee has confirmed that his version of the substance view would hold that the kitten substance ceases to be (is killed) when it is injected with the chemi cal, and a new rational substantive a 'human person' for Friberg Fernros comes into existence in its place. See M. Tooley. Abortion and Infanticide. Philos Public Aff 1972. 2(1): 3765.

${ }^{9}$ Friberg Fernros, op. cit. note 3, p. 211.

${ }^{10}$ Adapted from Lovering 2012, op. cit. note 1, p. 266.
} 
Lovering contends that the substance view would commit the officers to flipping a coin in this situation, but that this would be absurd. Most of us, he contends, believe we ought to save the boy in such a case. Substance view theorists George and Tollefsen agree, saying that most of us would save an older child over the embryo, but contend that this doesn't mean the embryo isn't inherently valuable and may be killed. ${ }^{11}$ To this, Lovering says:

George and Tollefsen are certainly correct on all counts: most people would save the five-year-old... and that most people would save the five-year-old does not entail that human embryos are not human beings (at least, genetically speaking) or that human embryos may be deliberately killed... Even so, George's and Tollefsen's answer misses the point entirely. This and other whom-should-you-save cases are invoked in an attempt to figure out whether we really believe (intuitively) that human embryos have the same intrinsic value and moral standing as individuals [whose deaths we agree would be a substantial loss], an essential step in the evaluation of arguments from inference to the best explanation. ${ }^{12}$

Friberg-Fernros summarizes this, saying 'Lovering consequently presupposes that one cannot prioritize the born human being at the expense of an embryo without denying the embryo the status of being a person. ${ }^{13}$ But, it seems, Friberg-Fernros misses the point as well insofar as most of us would prioritize the 10-year-old, this is evidence that we think the 10-year-old is, all things being equal, more morally important than the human zygote. The question, then, is how much more important is the 10 -year-old than the zygote.

\subsection{The Time Relative Interests Reply}

Friberg-Fernros proposes a possible explanation for why we would prefer to save the 10-year-old over the frozen embryo the former has what he calls 'a strong time relative interest'. ${ }^{14}$ A person has a strong time relative interest if there is a strong psychological unity between that person and their future selves. Embryos lack any psychological unity to their future selves, and thus lack any time relative interests.

Suppose that rather than choose whom to save, the police officers choose whom to kill. The killing of the embryo would be a violation of the embryo's right to life, but the killing of the 10-year-old child would both be the violation of the child's right to life and the violation of the child's time relative interests. This additional harm makes it worse to kill a substance with first-order

${ }^{11}$ George and Tollefsen, op. cit. note 5, p.139.

${ }^{12}$ Lovering, op. cit. note 1, p. 266.

${ }^{13}$ Friberg Fernros, op. cit. note 3, p.211.

${ }^{14}$ Ibid: 212. rationality than a substance that only possesses secondorder rationality.

Friberg-Fernros asks 'Now, what about the choice between 10 embryos and one child? ${ }^{15}$ Insofar as substance view theorists are not consequentialists, they need not choose the 10 over the one. However, he continues '[S]elf-evidently, all reasonable theories must stipulate that, ceteris paribus, one should choose to rescue more persons rather than fewer. The question is then, of course, whether the additional evils which are generated by the death of one child outweigh the death of 10 embryos. I think it can be reasonable to answer 'no' to that question.'

Despite this, just as many of us would prioritize the 10 -year-old boy over a single human embryo, it seems many of us would prioritize the 10 -year-old boy over 10 human embryos especially given there is no indication, let alone guarantee, that the embryos would ever be implanted! Friberg-Fernros is aware of this objection, though, and continues 'If that would be the only reasonable answer, then Lovering's charge of reductio ad absurdum would still stand. However, that is not the only reasonable response. ${ }^{, 16}$

Before we look at the other response Friberg-Fernros has in mind, it's important to note that the existence of another rational response will not save his position. What Lovering, and many of us, would find absurd here is the idea that, all else being equal, it would be reasonable to prioritize the 10 embryos over the one child. Even if we knew (contrary to statistics on spontaneous abortion) that all ten of the embryos, were they to be implanted, would grow into full persons, this would not be sufficient to get us all to prioritize them over the child. But why not? One explanation is that we don't find second-order rationality (the capacity to become a rational moral agent) to be anywhere near as valuable, morally, as the first-order rationality the child presently possesses; but this explanation would undermine the anti-abortion substance view position.

To illustrate another reasonable response, FribergFernros asks us to consider choosing between saving either one 10 year-old child or two infants. Many of us, he says, would choose the child over the infants. The reason one might choose this way, he says, relates to time relative interests. Friberg-Fernros seeks to show that the reason for choosing the 10 -year-old over two infants is not stronger than choosing the 10-year-old over 10 embryos; as such the substance view would be open to choosing a single human person over 10 human person embryos. He says:

Firstly, I think that one prevents more additional evil in choosing to rescue the 10 -year-old child over

15 Ibid.
16 Ibid. 
the two infants. For example, in ordinary cases, the death of two infants will cause more grief than the death of ten embryos, which means that the net effect of preventing additional evil is probably greater in the former compared to the latter case. ${ }^{17}$

What Friberg-Fernros seems to miss here is that the substance view like most anti-abortion positions contends that the loss of a human life is one of the worst evils that can occur. It is hard to imagine that any amount of grief could outweigh the loss of even one human life for such views. ${ }^{18}$ The fact that more people would mourn the loss of a single child than the loss of two infants or ten fetuses is, in itself, evidence that we place more value on the child than infants or fetuses.

Next Friberg-Fernros notes the high mortality rate of human embryos, contending that the difference in survivability between infants and embryos is another relevant factor for substance view theorists. However, this line of reflection, too, seems to miss the point. For the substance view theorist, a frozen human embryo already has a full right to life, regardless of whether or not it is implanted; its life is said to be, all else being equal, comparable to the life of you or me, as would its premature death. The fact that embryos are less likely to survive than non-embryos would not be sufficient to show that their lives are less worth preserving; at best it would show that their lives are less likely to be successfully preserved. However, this might just as easily count as evidence that we should be more concerned with trying to mitigate risks to embryos than infants because the former are in more danger than the latter; after all, infants are certainly less likely to survive than teenagers, but parents with multiple children are clearly morally justified in focusing their attention on their more at-risk children, all else being equal.

Because human embryos can survive frozen for quite some time, our moral obligations to provide them with the means for a good life may take a back seat to our duties to presently born people (who cannot simply be frozen and provided for later), but this ability to defer our obligations does not make them lesser organisms for the substance view. In fact, in some scenarios, this fact may make the difference between saving a single human embryo and a single 10-year-old child. For example, in lifeboat cases, it may be easier to keep a single human

\footnotetext{
17 Ibid: 213.

${ }^{18}$ This stands in sharp contrast to consequentialist theories; consider act utilitarianism, the consequentialist normative ethical theory that says the right thing to do in any situation is to act to maximize overall happi ness; for the utilitarian it would be morally required to kill innocent peo ple if doing so resulted in a net gain of happiness for all those affected. On such a view, we could kill innocent people on live television if enough people enjoyed the spectacle to outweigh the loss of utility of said inno cent people, and all the spectators who would be (understandably) horri fied by such a spectacle.
}

embryo frozen than to feed a 10 -year-old child; and if rescue is uncertain, the substance view theorist ought to prioritize the frozen embryo over the 10-year-old child. If we find such a conclusion absurd, so much the worse for the substance view.

\subsection{Is Friberg-Fernros's Substance View Anti- Abortion?}

Friberg-Fernros says:

[S]ince the magnitude of additional evil generated by our choices and the survival probability of the rescued entities are relevant factors to consider for the proponents of the substance view when they determine what choice should be made in this situation, it follows that the quantitative difference between rescuing one 10-year-old child over two infants compared with rescuing one child over 10 embryos, is not necessarily decisive for proponents of this view. ${ }^{19}$

Proponents of the substance view contend that abortion is a serious moral harm the killing of a (secondorder) rational substance with a full right to life whose life it would be seriously wrong to end. However, on Friberg-Fernros's account, the life of a fetus, it seems, is not all that wrong to end. Although the substance view maintains that a human fetus is the same kind of substance as a 10-year-old human child; Friberg-Fernros seems to be committed to defending the reasonableness of our giving preference to a single 10 -year-old human child over a substantively larger number of infants or fetuses; he explains that the additional badness of the deaths of those human substances could be outweighed by the loss of the single child's time relative interests and/or because more people would mourn his loss than that of the infants or fetuses.

It makes sense to say that grief is morally relevant; if one was faced with a choice between two options that produced different amounts of grief, but that were otherwise morally equivalent, there is good reason to think one should choose the option that would produce less grief, as grief is prima facie morally undesirable. Yet, for most of us, it seems the prevention of grief is a relatively low priority compared to the prevention of the loss of human life. It strikes me as quite absurd to suggest that the amount of grief that one would feel over, say, the loss of a famous, well-liked actor, would outweigh the loss of life of an additional person (or nine additional people); so let us set aside the grief argument and focus on the importance of time relative interests.

Jeff McMahan contends that what makes the deaths of beings like you or me seriously morally bad is that we possess first-order rationality. In contrast, beings like

19 Ibid 213. 
fetuses and infants, which possess only second-order rationality, the badness of their deaths is determined by their time relativist interests. However, for the first several months of pregnancy human fetuses lack time relative interests, and in light of this he concludes that abortion is not seriously morally wrong. ${ }^{20}$ It is, at least according to this view, not the killing of something with the same moral weight as you or I.

If Friberg-Fernros is committed to the claim that allowing two infants to die is less bad than allowing one 10 -year-old child to die, it seems he is committed to this claim because the additional harm to the 10-year-old child's time relative interests makes it so. This suggests that the violation of the child's time relative interests is at best a comparable evil to the loss of a single additional infant's life, or nine additional embryos' lives. But the anti-abortion substance view theorist would find this absurd, as it would commit us to conclude that the loss of a normal human's life is several times worse than the loss of a fetus; but the substance view theorist's criticism of abortion rests upon the notion that abortion the killing of a human fetus is the same kind, and degree, of evil as the killing of an adult human person. If the substance view theorist held that abortion were a lesser evil say comparable to jaywalking or purse snatching then there would be much less urgency and fervor in the debate.

If Friberg-Fernros's version of the substance view is committed to the view that the loss of several rational substances' lives is outweighed by the frustration of another's time-relative interests, then it would be committed to accepting most abortions. For example, it seems it might be committed to concluding that abortion might be morally acceptable even obligatory in the following case:

A woman genuinely wants to give birth to, and raise, children of her own. She becomes pregnant. In her seventh month of pregnancy, the woman recalls that she had scheduled her dream trip abroad and wants an abortion to avoid the nuisance of postponing the trip. She believes that she can always get pregnant with a replacement fetus after the trip. ${ }^{21}$

Pro-choice theorist Judith Jarvis Thomson contends that it would be indecent of a woman to get an abortion in such a case; yet Friberg-Fernros's analysis seems to suggest that abortion might be morally obligatory, as failure to abort frustrates her time relative interests in her dream trip. If the time relative interests of a 10-yearold child outweigh the evil produced by nine additional

20 J. McMahan. 2002. The Ethics of Killing: Problems at the Margins of Life. Oxford University Press, Oxford.

${ }^{21}$ J.J. Thomson. A Defense of Abortion. Philos Public Affs 1972; 1(1): 4766. human embryo-deaths, then it is at least plausible that the time relative interests of the woman in her dream trip might outweigh the evil produced by one human embryo-death. Compared to this, the majority of abortions done by pregnant women who do not want a child would seem downright quaint and unproblematic on Friberg-Fernros's view.

A substance view theorist might be able to avoid this conclusion by appealing to some additional factor beyond expected grief and additional frustration of timerelative interests that would allow them to explain why we ought to save a single 10-year-old child's life over that of two infants or 10 fetuses, but not sacrifice fetuses to prevent the frustration of the woman's time relative interests regarding her trip. Friberg-Fernros does not do this, and it's not clear what factor could fill this role.

\subsection{The Problem of Spontaneous Abortion}

Many pregnancies upwards of $60 \%$ end in spontaneous abortion. In light of this, Lovering says 'Given [the substance view], what this means is that beings with intrinsic value and moral standing equal to individuals [whose deaths we agree would be a substantial loss] are perishing annually in astonishing numbers. ${ }^{22} \mathrm{He}$ continues 'I know of no one... who has given any (let alone serious and considerable) consideration to thwarting the 'epidemic' of spontaneous abortions.' If the substance view is right, and the loss of the lives of human fetuses is comparable to the loss of your or my life, then 'our failure to give serious and considerable consideration to and, in turn, attempt to do something about this 'epidemic' is almost certainly immoral.'

The problem of spontaneous abortion is, in fact, two problems, that follow analytically from the tenets of the substance view.

(6) Spontaneous human abortion is the loss of inherently valuable beings. (From (2), (4))

In light of (6), it seems that substance view theorists ought to hold the following three things to be true - insofar as spontaneous human abortion is the loss of something with the same value as you or I:

(7) Because the loss of a spontaneously aborted child is comparable to the loss of you or I, we ought to mourn this loss.

(8) We have a strong moral obligation to prevent the loss of inherently valuable beings.

(9) We have a strong moral obligation to prevent spontaneous human abortions if possible. (From (6), (8))

${ }^{22}$ Lovering, op. cit. note 1, p. 268. 
However, it seems as though substance view theorists fail to recognize either (7) or (9). There is no impetus to mourn the dead lost through spontaneous abortion. Furthermore, substance view theorists spend far more time talking about the loss caused by induced abortion than the far higher losses resulting from spontaneous abortion, suggesting they don't care about the latter.

\subsubsection{The Control Principle Reply}

Friberg-Fernros's reply to the problem of spontaneous abortion focuses exclusively on our moral obligations with regard to preventing spontaneous abortions. $\mathrm{He}$ notes that we cannot be morally obligated to do the impossible; ought implies can. Insofar as we cannot at least at present stop spontaneous abortions, we cannot have the moral obligation to do so. According to the control principle, moral responsibility requires control; a necessary, but not sufficient, condition of $x$ 's being morally responsible for some $y$ is that $y$ is within $x$ 's control. Because it's outside of our control whether or not spontaneous abortions occur, we cannot be morally responsible for failing to stop spontaneous abortions.

Friberg-Fernros, like George and Tollefsen before him, note that many spontaneous abortions result from flaws in the human embryo that reduce its viability. ${ }^{23}$ While Friberg-Fernros raises this in regard to our moral obligations (if these fetuses are going to die regardless of what we do, we cannot be morally obligated to prevent their deaths); George and Tollefsen's discussion of these abortions as inevitable has different significance. On their view, if these abortions are the destruction of a substance that can never achieve first-order rationality, then they lack second-order rationality and are thus not (second-order) rational substances/humans/persons. This is to say that a large percentage of spontaneously aborted embryos are not human (in the sense relevant to substance view theorists; although they are biologically human). Assuming that $60 \%$ of pregnancies end with spontaneous abortion, and $50 \%$ of those pregnancies end because of the lack of viability of the fetus; it seems that the substance view theorist might be committed to the view that only $70 \%$ of fertilized human egg cells are (second-order) rational substances/persons from the moment of conception, because $30 \%$ are doomed to spontaneously abort. If this is the case, then for the substance view theorist, abortion is not always wrong because fetuses are often not human persons with a full right to life from conception.

It is uncontroversially true that most pregnant women are first-order rational substances whose deaths would be a significant moral loss. Certainly some spontaneous abortions pose a threat to pregnant women, as such the induced abortion of a non-human substance fetus would

${ }^{23}$ Friberg Fernros, op. cit. 214; George \& Tollefsen, op. cit. note 2, p. 137. be desirable independent of any concerns about the woman's time-relative interests and insofar as the woman is a first-order rational substance, substance view theorists would have substantive moral reasons to pursue technology that would allow us to distinguish between zygotes with second-order rationality and those without it. The lack of interest in this issue by substance view theorists is, to borrow Lovering's terminology, 'almost certainly immoral'. ${ }^{24}$

Suppose that we discovered some chemical that, when injected into one of these embryos otherwise doomed to spontaneously abort, would make the embryo viable. One might think the substance view would advocate using such a chemical to cure the fetus; not so. Whether or not a thing possesses second-order rationality is an essential substantial trait for substance view theorists; if these fetuses lack this trait, then giving them this trait would be forcing them to undergo a substantial change destroying the original unviable fetus, and replacing it with a new entity. This is a subtle distinction that allows the substance view theorist to completely disregard unviable fetuses, but I suspect this distinction would be rejected by the majority of anti-abortion advocates who appeal to the substance view to explain their antiabortion beliefs.

In light of the fact that we cannot (and, for the substance view, have no obligation to) save $50 \%$ of spontaneously aborted fetuses, what are our obligations? Friberg-Fernros says 'Admittedly, we currently are in a situation where we do have possibilities to attempt to do something about embryo loss. ${ }^{25}$ However, preventing such losses, he contends, is very difficult. Many spontaneous abortions occur before the woman is even aware that she is pregnant, about which he says 'a fact which also makes it hard to see how one 'can' do anything about it.'

Not so! If one was serious about preventing spontaneous abortions and advocates of the substance view really ought to be then the answer is clear; a woman who has engaged in activities that might foreseeably result in pregnancy should err on the side of caution, and assume they are pregnant until medical testing proves beyond a shadow of a doubt that they are not.

Suppose that you are backing out of a parking spot with your vision obstructed such that you cannot be sure whether or not you're backing into vulnerable pedestrians. It strikes me that you should back out slowly, and should not take any risks that would result in pedestrian harm if a pedestrian happened to be in your blind spot. Friberg-Fernros' view, on the other hand, seems to suggest that you should disregard your blind spots when pulling out ensuring that you don't run over your neighbor's children, after all, is difficult at least

\footnotetext{
${ }^{24}$ Lovering, op. cit. note 1, 268

${ }^{25}$ Friberg Fernros, op. cit. note 3, p.214.
} 
compared with the alternative of ignoring the possibility of their existence entirely and doing whatever you please.

If the substance view is correct, then women who might be pregnant are, at least, prima facie morally obligated to act cautiously. The cost of failing to do so, after all, might be by assumption comparable to the loss of a full human person like you or I. However, few antiabortion theorists that appeal to the substance view believe that women have such obligations.

\subsection{The Relevance of Spontaneous Abortion}

Suppose that our current medical technology can do nothing to prevent spontaneous human abortions. Many inherently valuable substances due to mysterious circumstances die before they are ever born, before they acquire time relative interests. Because we cannot be morally obligated to prevent something that we have no control over, we cannot be morally obligated to prevent (many) spontaneous abortions. However, this does not mean that spontaneous human abortions are morally irrelevant; far from it. For the substance view, spontaneous abortions are an epidemic - the loss of untold inherently valuable human beings due to circumstances beyond our control.

Suppose that, on the way home one night, you came to learn that two thirds of all human beings had just been killed by circumstances beyond your control for example, an earthquake, pandemic, or alien invasion. Fortunately for you, the aliens slaughtered only people who you didn't personally know (perhaps located on the other side of the globe). I imagine many of us would be quite devastated at the loss of life regardless of the fact that they're strangers. More importantly, we would want to know why it happened so that we can take steps to prevent such horrors in the future! Lovering's criticism of the substance view is simply this: The substance view holds that there is a horrible, substantial loss of life currently going on that results in more innocent human substances being killed than innocent human substances ever born; yet substance view theorists let this incalculable tragedy go unmentioned. The fact that there are no obvious dead bodies is no excuse for substance view theorists to ignore the incredible loss of lives that surrounds them. To do so is monstrous, and to mourn the deaths of human fetuses killed by induced abortion but not that of those killed by spontaneous abortion is hypocritical.

\section{CONCLUSION}

In this article I have argued that Friberg-Fernros's response to Lovering's critique of the substance view is unsatisfactory. Lovering argues that the substance view is committed to the position that human fetuses are morally equivalent to the adult human persons, but that our intuitions in rescue cases suggests otherwise. Furthermore, he argues that if the substance view is to be consistent, it should regard the loss in a spontaneous abortion as comparable to the loss of other fetuses, which again for the view would be comparable to the loss of adult human persons like you or I. FribergFernros argues that the loss of a non-fetus human person is substantively worse than the loss of human fetuses, but this view would be rejected by most substance view theorists and is inconsistent with the anti-abortion substance view argument. The substance view argues that abortion is seriously morally wrong because it is the death of full human persons comparable to you or I; but if Friberg-Fernros is correct, then the substance view cannot argue any such thing; on his view the death of human zygotes is morally insignificant compared to the loss of adult human persons that are more likely to survive, possess more time-relative interests, and for whom apparently more people would grieve. Indeed, if FribergFernros's account of the role of time relative interests is correct, then many abortions are not only morally acceptable, but morally obligatory. Friberg-Fernros's defense of the substance view commits him to what can be described as a 'pro-abortion' stance, the view that that in many cases a woman's time-relative interests make it morally obligatory for her to have an abortion even if she otherwise wants to have a child. On this view, a woman would only be morally permitted to go through with a pregnancy if the burden of pregnancy didn't significantly conflict with her time-relative interests. On this view, some women who want to give birth would be morally permitted to go through with pregnancy, but quite a few women who otherwise would want to have children might be morally obligated to have an abortion and have a replacement child at some point in the future that didn't conflict with their other time-relative interests. Not only has Friberg-Fernros failed to satisfactorily address Lovering's concerns about the substance view, he has offered an interpretation of the view radically inconsistent with the views held by anti-abortion theorists who appeal to the substance view to explain their position on abortion. 